Iveta Šafratová

\title{
KIND PRENOMINAL AND POSTNOMINAL ADJECTIVES IN CZECH
}

\begin{abstract}
In this paper, I investigate prenominal and postnominal adjectives in Czech for their syntactic and semantic properties. I claim that both types of adjectives can refer to kinds. Still, they differ with respect to the nature of the kinds they designate: postnominal kind adjectives are reserved for natural kinds, whereas prenominal kind adjectives indicate kinds created artificially. For this purpose, I assume that the kind domain is split into two sub-domains and the resulting surface structure is caused by the movement of a noun. I postulate a reformulation of the standard entailment-based typology test to prove that both types of kind adjectives are intersective adjectival modifiers.
\end{abstract}

\section{KEYWORDS}

kind; prenominal adjectives; postnominal adjectives; Czech

\section{Introduction}

The phenomenon referred to as the kind/object distinction has been studied for a long time (KRIFKA - GERSTNER 1987, KRIFKA et al. 1995, CARLSON 1977, and many others). CARLSON (2006) characterizes kind as a classification system that is based on the denotations of nominal expressions, or sortals, of the language. Expressions referring to a kind do not denote individual objects or groups, but rather they denote a kind itself.

In terms of kind reference, linguists focus mainly on definite/indefinite descriptions and bare plurals, but surprisingly they do not pay much attention to kind adjectives. This is even more remarkable because these adjectives occur in several Slavic languages. As far as I know, WĄGIEL (2014) was the first one who has shown on Polish data that kind adjectives are always closer to a noun than object adjectives. Wągiel argues that Polish adjectives can switch from the kind denotation to the object denotation via certain semantic operations. At first blush, Czech 
adjectives behave in the same way as Polish adjectives. They can denote either kinds or objects depending on their syntactic position, and the syntactic restriction goes hand in hand with their semantic properties. A more profound exploration of Czech adjectives leads me to deal with some challenges that I address in this article.

Let me first discuss Czech attribute adjectives in postnominal position in general. In Czech, at least three types of the use of attributive postnominal adjectives can be distinguished. The first type is such that adjectives contrast each other, as in (1). The adjective velké 'big' appears prenominally, and it is unmarked. On the other hand, the adjective malé 'small' is in postnominal position and as such is emphasized.
(1) Ona si nekoupila velké auto, ona si koupila auto malé. she REFL NEG-bought big car she REFL bought car small 'She did not buy a big car, she bought a small car.'

Adjectives corresponding to relative clauses are the second type. The postnominal adjectives keep the interpretation of the relative clauses, and they replace the relative clauses, compare (2a) and ( $2 b)$.

(2) a. Ten kluk zpivajici pisničku je můj bratr.
the boy singing song is my brother
'The boy singing the song is my brother.'
b. Ten kluk, ktery zpivá pisničku, je můj bratr.
the boy who sings song is my brother
'The boy who is singing the song is my brother.'

The last type represents postnominal adjectives that are the core of this article. They are called kind adjectives, and as such, the postnominal position is unmarked for them (3).

\section{(3) Vidím leguána galapážského. \\ I-see iguana Galapagian \\ 'I see a Galapagos land iguana.' (a representative of the species Conolophus sub- cristatus)}

In this paper, I argue that Czech postnominal adjectives denote kinds in default utterance, i.e., adjectives are not in contrast, or they do not substitute relative clauses. Czech prenominal adjectives primarily denote an object, as the adjective velký 'big' in (1), but moreover, they can refer to kinds under certain circumstances.

Following WĄGIEL (2014), I analyze Czech adjectives that, as well as Polish adjectives, can occur in prenominal or postnominal position. Czech adjectives can refer to objects in both prenominal and postnominal position, i.e., they can have an existential reading. I omit this reading, and I investigate whether a generic reading is 
possible regardless of the syntactic position of adjectives. I focus only on attributive adjectives without other modifiers.

I aim to distinguish between prenominal and postnominal kind adjectives. In Section 2, I investigate Czech prenominal and postnominal adjectives from the semantic point of view. I show that standard entailment-based typologies cannot be applied to kind adjectives, and therefore, the adjective classification has to be modified. In Section 3, I argue that the restrictive use of adjectives is a valid argument for claiming that they refer to kinds. In the Section 4, I argue that prenominal and postnominal adjectives have a slightly different kind interpretation, which is caused by a different syntactic structure to be depicted in Section 5 .

\section{Typology of adjectives}

In this section, I focus mainly on an entailment-based typology that distinguishes between two groups of adjectives by default, namely intersective adjectives and non-intersective adjectives. More specifically, they are called intersective adjectival modifiers and non-intersective adjectival modifiers because we are interested in environments when they modify nouns. ${ }^{1}$ Following McNaLly (2016), I use the entailment-based typology for the classification of adjectives that distinguishes between intersective adjectives and non-intersective adjectives. ${ }^{2}$ Intersective adjectives are such for which the following pattern in (4) is valid.
(4) a. Adora is a brown dog.
b. FAdora is brown. (brown color)
c. $\vDash$ Adora is a dog.

The sentence in (4a) entails (4b) as well as (4c). The denotation of the whole phrase [brown dog] is a result of the intersection of the set denoting dogs and the set denoting brown entities. The statement in (4a) belongs to the intersection of both sets in (4b) and (4c). In other words, if it is true that Adora has the property of being brown, and if it is true that Adora is a dog it has to be true that Adora is a brown dog. It is due to Predicate Modification which can be applied to intersective adjectives (5).

$$
\text { (5) } \llbracket \text { Adora is a brown } \operatorname{dog} \rrbracket=\lambda x[\operatorname{dog}(x) \wedge \operatorname{brown}(x)] \text { (adora) }
$$

\footnotetext{
1 Non-intersective adjectival modifiers can be further divided into several subgroups.

2 It is important to mention that MCNALLY (2016) does not classify adjectives solely, but modifiers in general. McNally distinguishes modifiers from three perspectives. In this article, I adopt only one point of view, namely, an entailment-based typology that is one of the most used classifications in formal semantics.
} 
The entailment from a proposition such as $(6 a)$ to both (6b) and (6c) does not hold for non-intersective adjectives.
(6) a. Ann is a skillful painter.
b. $\vDash A n n$ is a painter.
c. \#Ann is skillful.

Contrary to the previous example (4), the sentence (6a) entails (6b), but it does not entail (6c) because Ann can be skillful only in the field of painting but not in other fields. The denotation of the whole phrase [skillful painter], which involves the nonintersective adjective skillful, does not result from the intersection of the denotation of the noun painter and the denotation of the adjective skillful. Rather, the adjective skillful restricts the denotation of the noun painter. In the case of non-intersective adjectives, we cannot use Predicate Modification, but rather Functional Application has to be applied (7).

\section{(7) $\llbracket$ Ann is a skillful painter $\rrbracket=\lambda x[($ skillful $($ painter $))(x)]($ Ann $)$}

The remaining part of this section investigates kind adjectives using the entailment-based typology test. I start with WAzGIEL's (2014) observations about Polish kind adjectives, and then Czech data will follow. I show that Czech kind adjectives behave much like Polish kind adjectives, but not entirely.

\subsection{Polish data (WĄGIEL 2014)}

The main generalization of Wagiel's proposal is that Polish postnominal adjectives refer to kinds and prenominal adjectives denote individual objects. He starts with an observation that some adjectives can denote an object or a kind depending on their syntactic position relative to the noun. The following example (8) shows that Polish color adjectives can occupy both syntactic positions, but with a different semantic interpretation (WĄGIEL 2014, ex. (10)).

(8)
a. czarny
dzięcioł
black
woodpecker
b. dzięciot
czarny
woodpecker black

WAqGIEL $(2014,462)$ claims that the adjective czarny 'black' in prenominal position in (8a) indicates that the color of woodpecker is black, however, the example (8b), where the adjective 'black' is postnominal, does not mean that the color of woodpecker is necessarily black, but rather it refers to a representative of the species Dryocopus martius. Based on the Polish data, Waggiel states that prenominal adjectives only have an existential reading because they denote an object, whereas post- 
nominal adjectives are ambiguous between a generic and an existential reading because they can refer either to a kind or to an object.

Using the entailment-based test, Wągiel claims that Polish adjectives are intersective, i.e., the meaning of the whole phrase is an intersection of the set denoting a noun and the set denoting an adjective, as in (9) (WĄGIEL 2014, ex. (11)).

(9) a. Kajtek to czarny dzięciot.

Kajtek this black woodpecker

'Kajtek is a black woodpecker.' (= a woodpecker whose color is black)

b. ₹ Kajtek to dzięciot.

Kajtek this woodpecker

'Kajtek is a woodpecker.'

c. ₹ Kajtek jest czarny.

Kajtek is black

'Kajtek is black.'

In the next step, Waggiel focuses on postnominal adjectives and argues that the adjective black is non-intersective in this situation (10), as can be witnessed by the entailment-based test because (10a) entails (10b) but does not entail (10c). The meaning of the statement (10a) does not result from the intersection of the set denoted by the noun in (10b) and the set denoted by the adjective in (1OC) (WĄGIEL 2014, ex. (12)).

(10) a. Kajtek to dzięciot czarny.

Kajtek this woodpeckerblack

'Kajtek is a black woodpecker.' (= a representative of the species Dryocopus martius)

b. $\vDash$ Kajtek to dzięciot.

Kajtek this woodpecker

'Kajtek is a woodpecker.'

c. \# Kajtek jest czarny.

Kajtek is black

'Kajtek is black.'

The statement (10a) does not entail (10c) because we have to take into account that the whole phrase [woodpecker black] is not about an individual being black (black color) but about the individual Kajtek that is a representative of the species Dryocopus martius and that could be an albino.

According to WĄGIEL (2014), it appears that postnominal kind adjectives have subsective semantics but (following MCNALLY - BOLEDA 2004) this can be accounted for in terms of intersective semantics with the postnominal adjective predicating a property of a kind-level individual. Therefore, postnominal adjectives are also intersective modifiers, the only difference is that they denote properties of kinds rather than object-level entities. Wągiel's observations concerning Polish adjectives are summarized in Table 1. 


\begin{tabular}{|c|c|}
\hline $\begin{array}{ll}\text { Prenominal adjectives } \\
\text { czarny } & \text { dzięciot } \\
\text { black } & \text { woodpecker }\end{array}$ & $\begin{array}{l}\text { object denoting } \rightarrow \text { existential reading } \\
\text { intersective }\end{array}$ \\
\hline \begin{tabular}{ll}
\multicolumn{2}{l}{ Postnominal adjectives } \\
dzięciot & czarny \\
woodpecker & black
\end{tabular} & $\begin{array}{l}\text { object denoting } \rightarrow \text { existential reading } \\
\text { kind denoting } \rightarrow \text { generic reading } \\
\text { intersective }\end{array}$ \\
\hline
\end{tabular}

Table 1 Generalization on Polish adjectives

\subsection{Czech data}

I propose a slightly modified entailment-based test that supports the hypothesis about the intersective properties of kind adjectives. I argue that the entailmentbased test applied to Czech adjectives is not entirely reliable because it gives doubtful results, as in (11). ${ }^{3}$
(11) a. Pierre je francouzský student.
Pierre is French student
'Pierre is a French student.'
b. FPierre je student.
Pierre is student
'Pierre is a student.'
c. "Pierre je francouzský.
Pierre is francouzský
'Pierre is French.'

The sentence (11a) entails (11b), but (11c) is ungrammatical. However, ungrammaticality does not necessarily mean that (11a) does not entail (11c). Therefore, it seems that the entailment-based test cannot be applied in Czech as it is, which leads me to a conclusion that it is necessary to reformulate the test and establish a new one. The required result could be obtained by adding new information, as in (12).
(12) a. Pierre je francouzský student.
Pierre is French student
'Pierre is a French student.'

3 Note that the example (11c) is ungrammatical itself for some independent reason. However, we can easily find similar examples that are grammatical, compare (i) and (ii). Adjectives denoting origin/ nationality can sometimes be used predicatively in Czech. Therefore, I believe that the ungrammaticality of (11c) is not a syntactic issue. Thanks to an anonymous reviewer for raising this point.

$\begin{array}{ll}\text { (i) Pierre je francouzský. } & \\ \text { Pierre is French }\end{array}$

(ii) 'Pierre is French.'

This movie is French

'This movie is French.' 
b. Pierre je také brigádník.

Pierre is also part-timer

'Pierre is also a part-timer.'

c. ₹Pierre je francouzský brigádník.

Pierre is French part-timer

'Pierre is a French part-timer.'

The reformulated test removed a deficiency in the form of ungrammaticality in the previous test. We had to reformulate in order to avoid the ungrammatical sentence Pierre is French. The second test proved that (12a) and (12b) entail (12c), and therefore, the adjective francouzsky 'French' is intersective.

At this point, I return to kind adjectives because it seems that now we have a more credible diagnostic for distinguishing between intersective and non-intersective adjectives. The standard test applied to postnominal kind adjectives (following MCNALLY 2006) made us believe that these adjectives are non-intersective because (13a) entails (13b) but does not entail (13c) considering that Quido may have been born in captivity.

(13) a. Quido je leguán galapážský.

Quido is iguana Galapagian

'Quido is a Galapagos land iguana.' (= a representative of the species Conolophus subcristatus)

b. FQuido je leguán.

Quido is iguana

'Quido is an iguana.'

c. \#?Quido je galapážský.

Quido is Galapagian

'Quido is Galapagian.'

The reformulated test could be hopefully applied not only to prenominal objectdenoting adjectives but also to postnominal kind-denoting adjectives.

(14) a. Toto je leguán galapážský.

this is iguana Galapagian

'This is a Galapagos land iguana.' (= a representative of the species Conolophus subcristatus)

b. Toto je samec.

this is male

'This is a male.'

c. \#?Toto je samec galapážský.

this is male Galapagian

'This is a Galapagian male.' 
The reformulated test does not improve the result of a sentence with a postnominal kind adjective. The sentence (14a) does not entail (14c), moreover (14c) seems to be ungrammatical. Therefore, we have to reformulate the test again; now we substitute the adjective galapážský 'Galapagian' with the synonymous prepositional phrase [z Galapág] 'from the Galapagos Islands'.

(15) a. Toto je leguán galapážský.

this is iguana Galapagian

'This is a Galapagos land iguana.' (= a representative of the species Conolophus subcristatus)

b. Toto je samec.

this is male

'This is a male.'

c. \# Toto je samec z Galapág.

this is male from Galapagos-Islands

'This is a male from the Galapagos Islands.'

Although (15c) is grammatical, (15a) still does not entail (15c) taking into account that the iguana does not necessarily come from the Galapagos Island since it can come from a pet shop (because it was born in captivity). ${ }^{4}$ We can, thus, tentatively conclude that the adjective francouzský 'French' in (12a) is intersective whereas the adjective galapážský ‘Galapagian' in (14a) is non-intersective. However, this result is surprising because both of them belong to the class of so-called relational adjectives. We could intuitively assume that the properties and the behavior of adjectives within one class are identical.

Hence, the second reformulated test remains problematic. If the adjective galapážský is indeed intersective, then the question arises, why even the application of the second reformulated does not give the desired result. The answer is staring us right in the face: the reformulated test fails because the adjectives in those examples are kind predicates. For that reason, the standard test (MCNALLY 2016) could not work because we tried to examine kind adjectives, but the test should be primarily used for object-denoting adjectives. With this in mind, I introduce the last reformulated version of the test that nicely captures the behavior of kind adjectives. The final modification correctly diagnoses the adjective galapážský as being intersective. The improvement relies on the fact that the noun druh 'species' is used as a subject of the predication in (16).

4 I do not claim that the PP $z$ Galapág 'from the Galapagos Islands' replacing the kind adjective galapážský 'Galapagian' can be interpreted as a kind phrase. I aim to show that the reformulated test correctly indicates that the postnominal adjective galapážský 'Galapagian' is intersective only if it refers to a species, not to an object. The replaced phrase z Galapág 'from the Galapagos Islands' is only intended to support this conclusion. 
(16) a. Tento druh zvírete je leguán galapážský.

this species animal is iguana Galapagian

'This animal species is the Galapagos land iguana.'

b. Tento druh zvírete je leguán.

this species animal is iguana

'This animal species is the iguana.'

c. F Tento druh zvírete je $z \quad$ Galapág.

this species animal is from Galapagos Islands

'This animal species is from the Galapagos Islands.'

The sentence (16a) entails (16c) and the statement (16c) is grammatical. The third reformulated test confirms the hypothesis that the adjective galapážsky is intersective; in this case, we have to intersect the set of species coming from the Galapagos Islands and the set of iguanas. At a more general level, the reformulated test allows us to examine both object-denoting adjectives and kind-denoting adjectives from the perspective of the entailment-based typology.

All difficulties in examples (14) and (15) were caused by the fact that the subject was the phrase referring to an object. When we switch the phrase referring to an object into a phrase referring to a species, the test determines the adjective galapážský as being intersective (intersective with respect to the given species of iguana, not to the particular individual that does not have to come from the Galapagos Islands as was mentioned above).

Assuming that the third reformulated test can distinguish between intersective and non-intersective kind adjectives, the following examples (17) and (18) should correctly differentiate between intersective and non-intersective postnominal kind adjectives.

(17) a. Tento druh zvířete je leguán galapážský.

this species animal is iguana Galapagian

'This animal species is the Galapagos land iguana.'

b. ₹ Tento druh zvírete je $z$ Galapág. this species animal is from Galapagos Islands

'This animal species is from the Galapagos Islands.'

(18) a. Tento druh zvírete je výr velký.

this species animal is eagle-owl big

'This animal species is the Eurasian eagle-owl.' (= a representative of the species Bubo bubo)

b. \# Tento druh zviŕete je velký.

this species animal is big

'This animal species is big.' 
Examples (17) and (18) confirm the assumption that kind adjectives can be both intersective (17) and non-intersective (18). ${ }^{5}$ The statement in (17b), i.e., 'This animal species is from the Galapagos Islands', is suitable, whereas the statement in (18b), i.e., 'This animal species is big', is not entailed. I suggest that this results from the fact that the adjective velky 'big' belongs to the class of non-intersective gradable adjectives (KENNEDY 2012). The observation concerning Czech adjectives made above is summarized in Table 2 below.

\begin{tabular}{|l|l|}
\hline $\begin{array}{l}\text { Prenominal adjectives } \\
\text { černý datel 'black woodpecker' } \\
\text { velký výr 'big eagle-owl' }\end{array}$ & $\begin{array}{l}\rightarrow \text { intersective } \\
\rightarrow \text { non-intersective }\end{array}$ \\
\hline $\begin{array}{l}\text { Postnominal adjectives } \\
\text { datel černý 'woodpecker black' }\end{array}$ & $\rightarrow$ intersective \\
\hline
\end{tabular}

Table 2 Generalization on Czech adjectives

I claim that kind adjectives can be distinguished in the same way as object-denoting adjectives, but kind-denoting adjectives have to be paraphrased as referring to a kind. The intersective/non-intersective property of object-denoting adjectives is attributed to individuals, whereas the intersective/non-intersective property of kind-denoting adjectives is only assigned to species. I propose that the reason why this is so, is that each individual belongs only to one species. The main difference is not the intersective or non-intersective property of adjectives but the fact whether the given adjective modifies a kind or not.

I argue that both object-denoting adjectives and kind-denoting adjectives can be distinguished based on their intersective/non-intersective property. Following WÁGIEL (2014), I assume that adjectives are ambiguous between those two types of denotations, and they can freely switch between them. The natural question is, what is the reason for the switch or, in other words, under what conditions is the ambiguity of an adjective possible since it seems implausible to be accidental. I will try to resolve the questions in the next section.

5 An anonymous reviewer opened a question of whether kind adjectives can be gradable; in this case, the adjective velký 'big'. The reviewer argues that the comparative form větši 'bigger' cannot be used to refer to the same type of owl. I agree with that. But if we take this point, what does it mean for kind adjectives? If we assume that kind adjectives are not gradable, can we keep the idea that kind adjective can be non-intersective? And if not, does it mean that all kind adjectives are intersective or do we have to completely rethink whether we can divide kind adjectives in the same way as non-kind adjectives. I still believe that we can divide kind adjectives and non-kind adjectives in the same way, but I leave the question for further research. 


\section{Restriction on kind adjectives}

I distinguish between object-denoting adjectives and kind-denoting adjectives using yet another semantic diagnostic, i.e., we can test adjectives for their restrictive/ non-restrictive usage. Restrictive adjectives have restrictive force: they restrict the meaning of a noun they modify in a certain way. By contrast, non-restrictive adjectives lack this force: the denotation of a noun they modify is not restricted; see Cinque (2010) or MORZYCKI (2008).

(19) Beautiful leopards are almost extinct.

a. Non-restrictive: Leopards are almost extinct. Leopards are beautiful.

b. Restrictive: Only beautiful leopards are almost extinct.

The non-restrictive use of the adjective beautiful (19a) does not restrict the denotation of the noun leopards. The whole sentence conveys that leopards are almost extinct and the adjective beautiful only expresses that leopards are beautiful. On the other hand, the restrictive use of the adjective beautiful (19b) restricts the denotation of the noun leopards. Only beautiful leopards become nearly extinct in this case which implies that ugly leopards do not become extinct.

I assume that the restrictive/non-restrictive use of adjectives can resolve the puzzle. Consider the next example:

(20) Context: There were several species of iguanas in a pet shop.

a. Petr si tam koupil všechny leguány galapážské.

Petr REFL there bought all iguanas Galapagian

'Petr bought all Galapagos land iguanas there.'

b. Petr si tam koupil všechny leguány.

Petr REFL there bought all iguanas

'Petr bought all iguanas there.'

The adjective galapážský 'Galapagian' clearly restricts the denotation of the noun meaning 'iguanas': in the given context, some iguanas (such that they do not belong to the species Conolophus subcristatus) stayed in the pet shop in (20a), but no iguanas were left in the pet shop in (2ob). This straightforwardly shows that kinddenoting adjectives can only have the restrictive use. This claim corresponds with the semantics of kind adjectives because kind modification needs a local scope. ${ }^{6}$ The non-restrictive modification requires a much wider scope, and therefore the nonrestrictive usage and kind modification should exclude each other because of the scope inconsistency. Table 3 summarizes the observations. 


\begin{tabular}{|l|l|}
\hline object-denoting adjectives & $\begin{array}{l}\rightarrow \text { restrictive usage } \\
\rightarrow \text { non-restrictive usage }\end{array}$ \\
\hline kind-denoting adjectives & $\rightarrow$ restrictive usage \\
\hline
\end{tabular}

Table 3. Restrictive/non-restrictive usage of adjectives

Now, I turn to Czech prenominal adjectives, and I analyze them in the same way as postnominal adjectives since they seem to be more complicated than Polish prenominal adjectives.

\section{Czech prenominal adjectives}

WĄGIEL (2014) argues that only postnominal adjectives can have a generic reading in Polish. However, we can find some prenominal adjectives in Czech that seem to have a generic reading as well, e.g., suchozemská želva 'terrestrial turtle', zelený čaj 'green tea', uzený sýr 'smoked cheese', sladkovodní ryba 'freshwater fish' and zubní sklovina 'tooth enamel'. Intuitively, the class of prenominal kind adjectives differs from the class of postnominal kind adjectives. Both classes refer to a kind; nevertheless, it seems that there are two different categories of kinds. A noun phrase with a postnominal kind adjective has an equivalent description in Latin, but the a noun phrase with a prenominal kind adjective lacks the Latin equivalent. We can say that a noun phrase with postnominal kind adjective refers to a natural species, unlike a noun phrase with a prenominal kind adjective. A kind referred to by prenominal adjectives is presumably created artificially. If we create a new kind, then an adjective modifying the noun phrase referring to that new kind is in prenominal position. I suggest that postnominal adjectives indicate an inherent kind property, whereas prenominal adjectives indicate an occasional kind property. This hypothesis is supported by Grimm and Levin who investigate natural kind nouns and artifact nouns and claim that the semantic representations of artifact nouns are distinct from those for natural kind nouns (for further discussion see GRIMM - LEVIN 2017).

If the assumption that there are two categories of kinds is on the right track, we should be able to test kind prenominal adjectives in the same way as kind postnominal adjectives in terms of the entailment property and the restrictive property. Below, I use a reformulated entailment-based test.
(21) a. Tento druh zvírete je
this species animal is
mořská želva.
'This animal species is the sea turtle.'
b. F Toto zvíre je želva. this animal is turtle
'This animal is a turtle.'



c. \# Toto zvíre je
mořské/ $z$
more.
this animal is
sea-ADJ from
sea
'This is a sea animal.'
d. ₹ Tento druh zvírete je mořský/z moře. this species animal is sea-ADJ from sea 'This is a sea animal species.'

(21a) entails (21b), but it does not entail (21c) because the relevant turtle does not necessarily come from the sea (it can come from a zoo where it was born in captivity). However, (21a) entails (21d) because it says that the species of the turtle comes from the sea (but it does not have to be true for an individual turtle as in (21c). Thus, we have proved that also prenominal adjectives can refer to kind. The second property to test is the restrictive usage.

(22) Context: There were several species of turtles in the zoo.
a. Petr vidè všechny mořské želvy. Petr saw all 'Petr saw all sea turtles.'
b. Petr viděl všechny želvy. Petr saw all turtles 'Petr saw all turtles.'

The adjective morský 'sea' restricts the noun želvy 'turtles' because (22a) states that Petr saw all the sea turtles, but he did not have to see terrestrial turtles, whereas, according to (22b), Petr saw all the species of turtles in the Zoo. The restrictive use of the prenominal adjective 'sea' is consistent with the claim that kind adjectives need a narrow scope relative to the noun.

\section{Syntax of Czech kind adjectives}

I argue that both prenominal and postnominal adjectives can have a kind reference. In this section, I show how their syntactic positions differ. I start with the minimal pair of adjectives that can occur in prenominal or postnominal position (23).
(23) a. zelená
muchomůrka
green
b. muchomůrka toadstool toadstool

\section{zelená}
green

\section{(=Amanita phalloides)}

The prenominal adjective in (23a) indicates an individual property of a toadstool, whereas the postnominal adjective in $(23 \mathrm{~b})$ indicates a kind property. We can say that postnominal adjectives refer basically to a set of kinds, whereas prenominal 
adjectives refer to a set of individuals. This phenomenon leads to the bracketing paradox (SPENCER 1988), which is demonstrated in (24) below.
(24) Petr upekl hřiby smrkové.
Petr baked boleti spruce-ADJ
'Petr baked spruce boleti.' (= a representative of the species Boletus edulis)

On the one hand, I argue that postnominal adjectives modify kinds, but, on the other hand, I do not want to claim that people can bake kinds because they eat individuals. What is pluralized are not kinds (Petr did not bake several kinds of mushrooms) but rather individuals (Petr baked several individuals). I assume that the adjective modifies only the root of the noun phrase (which denotes a kind), i.e., [[hřib $\left.{ }_{\text {root }}\right]$ smrkový], whereas the plural form of the noun, i.e., hřib-y 'boleti', refers to a plurality of entities. We can use the realization relation $R$ (CARLSON 1977) to distinguish between kind reference and individual reference. First, the adjective smrkovy 'spruce' combines with the root of the noun hrib 'boletus' which denotes a kind. 'Then, the root denotation of the noun is shifted to the set of individuals of a particular species via the realization relation $R$ (each individual is in the relationship to the particular species). The root moves via head movement, and thereby it moves over the kind adjective. Finally, the plural suffix is added which quantifies over individuals. Due to the proposed mechanism we can easily switch from kinds to objects, as in Figure 1.

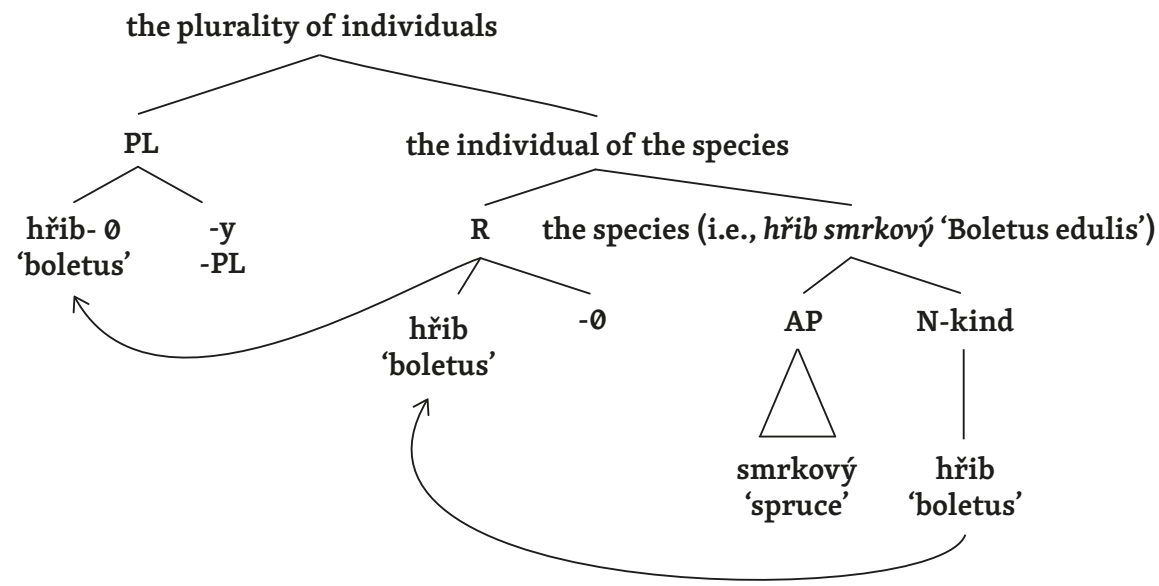

Figure 1 The Czech semantic tree: switching from kinds to objects

7 Due to limited space, I am not going into the discussion of the "root" definitions for individual syntactic analyses. I am aware of the fact that it is important to define the term "root" properly, but I use the term "root" in the classical sense. I utilize the term "root" as the smallest unit of meaning, being morphologically simple. 
This structure is not detailed enough because prenominal adjectives can refer to either a kind or an individual in Czech. I assume that the syntactic structures of kind adjectives and individual adjectives in the prenominal position are not identical. The essential assumption is that an adjective closer to the noun is more generic (have the kind reference) than an adjective standing further from the noun. Kind adjectives stand structurally closer to the noun, modify it earlier than individual adjectives and denote kind properties. A noun phrase referring to a kind is created, and it can be further modified by an adjective denoting individual properties.

WĄGIEL's (2014) syntactic structure indicates that the border between the individual domain and the kind domain is a nominal phrase in Polish. Everything inside the nominal phrase is generic, whereas other adjectives outside the nominal phrase are in the individual domain. The simplified syntactic tree illustrates the Polish example biały dzięcioł czarny 'white woodpecker black' (i.e., Dryocopus martius having a white color) is given in Figure 2 (WĄGIEL 2014, ex. (19)).

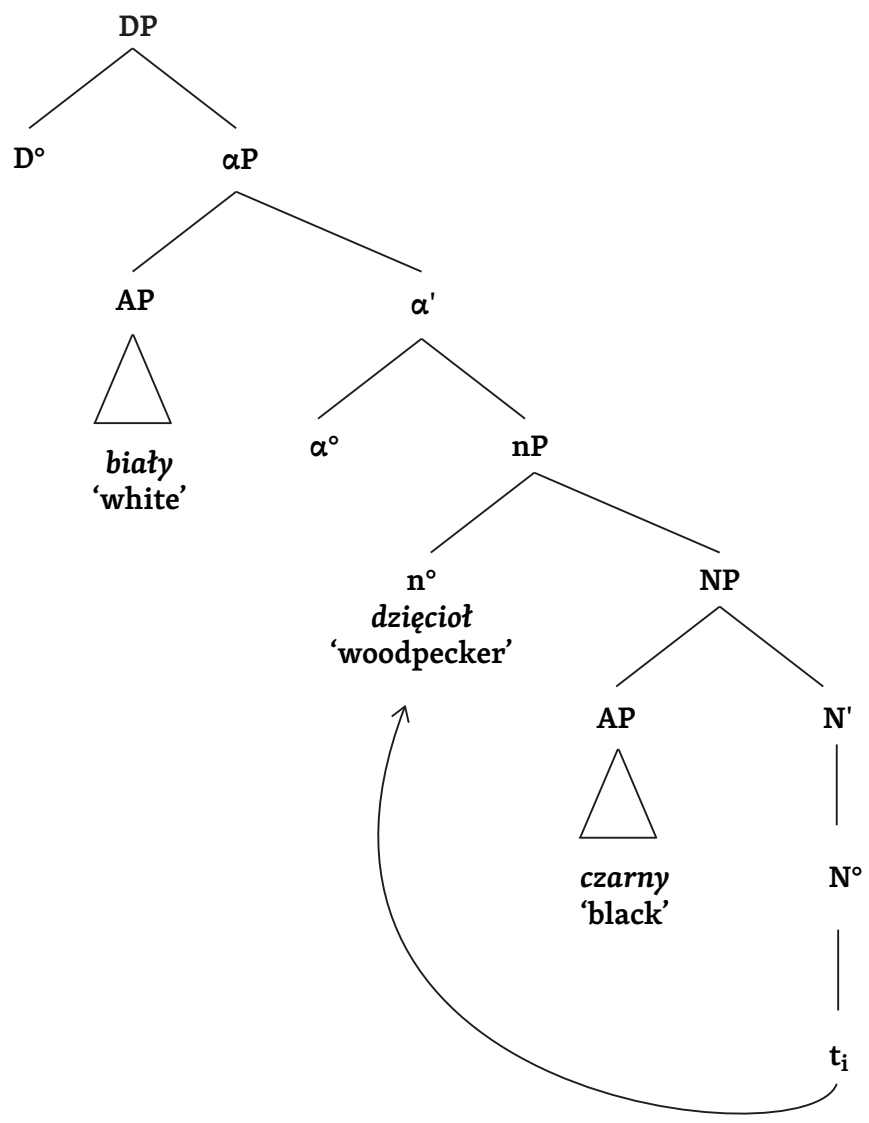

Figure 2 The Polish syntactic tree of individual and kind adjectives 
Since the individual domain is located above the kind domain, we can further divide the kind domain into two sub-domains. Adjectives denoting inherent kind properties are located closest to the noun, and above them, there are adjectives denoting occasional kind properties. The individual domain is located above the second kind domain. The noun moves to the left above an adjective denoting inherent kind properties in Czech. The final syntactic structure is given in Figure 3.

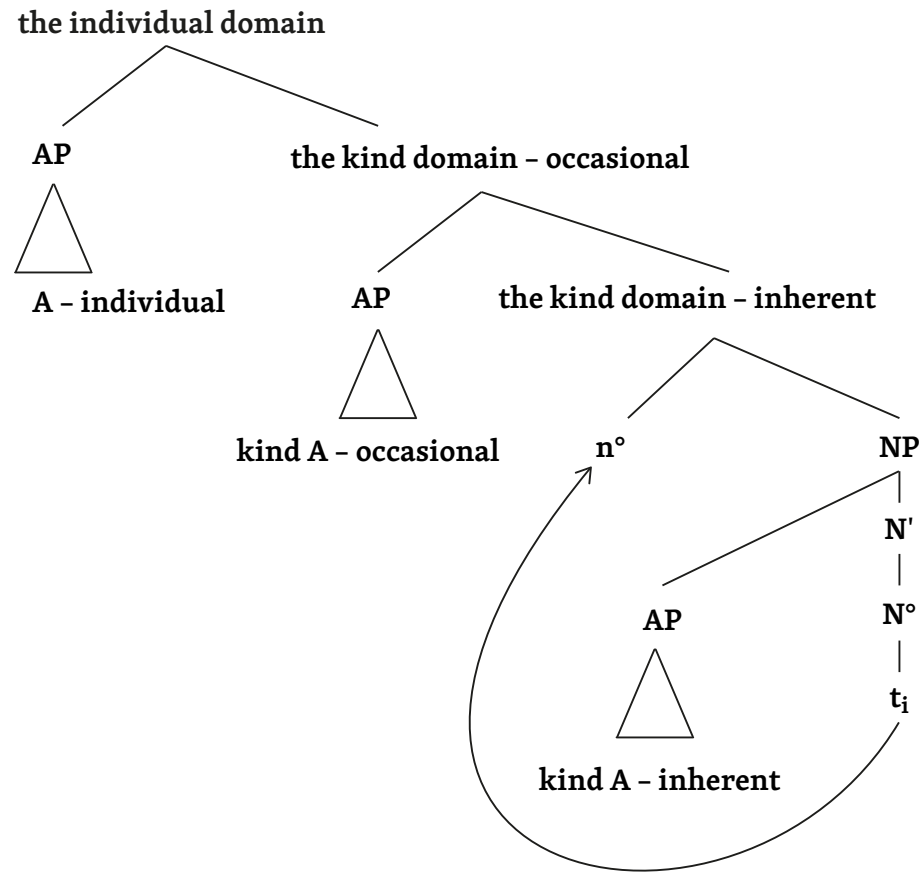

Figure 3 The syntactic tree of different adjective domains in Czech

The fact that all kind adjectives are only postnominal in Polish results from the movement of the noun. The noun moves higher in Polish than in Czech, namely above the occasional kind domain. Following CinQue (2014), I argue that initially all adjectives are prenominal, but the movement of the noun makes them postnominal in the surface syntax. The occurrence of prenominal kind adjectives depends on the movement length of the noun in a particular language. I propose that the movement distance is longer in Polish than in Czech because Polish nouns move above the occasional kind domain, and therefore, the occurrence of prenominal kind adjectives is blocked. Prenominal kind adjectives in Czech are possible because nouns move below the occasional kind domain.

On my proposal, Czech inherent kind adjectives, i.e., adjectives introducing properties of natural kinds, differ from other adjectives in that they are structurally closest 
to the noun. Specifically, inherent kind adjectives are base generated in the SpecNP and are associated with the strong feature [+inh.kind] that has to be checked by the noun. Consequently, the noun moves to $n^{\circ}$, i.e., the head of the special projection, which is an immediate functional extension of the NP (the first functional projection above the NP). As a result, it ends up preceding the kind adjective in the surface syntax, or in other words, inherent kind adjectives are always postnominal.

On the other hand, Czech occasional kind adjectives, i.e., adjectives introducing properties of kinds created artificially, are simply base-generated within the first AP above the nP. I assume that the hierarchy of APs is ordered along the lines of a Cinque-style approach so in the surface syntax they will be always occupy the first prenominal slot relative to the noun.

\section{Conclusion}

This article aims to shed new light on the issue of kind adjectives in Czech. I show that some Czech adjectives can refer to an occasional kind [zelený čaj] 'green tea', i.e., we select one sub-kind from the kind tea, and then we can generically-intersectively attribute properties to that sub-kind [freshly brewed [green tea]].

I argue that the distinction between prenominal and postnominal kind adjectives is affected by the difference between natural kinds and occasional kinds. Nouns move over the inherent kind domain, and therefore natural kind adjectives appear in postnominal position on the surface. The occurrence of occasional kind adjectives is limited to the occasional kind domain exclusively, which causes that these adjectives appear prenominally.

The unresolved question remains how and whether it is needed to distinguish the syntactic difference between prenominal and postnominal kind adjectives from the formal semantic point of view. Predicate Modification has to be used for both types of adjectives. I leave this issue open for future research.

\section{REFERENCES}

Carlson, Gregory. 1977. Reference to Kinds in English. Massachusetts. Doctoral thesis, University of Massachusetts.

CARLSON, Gregory. 2006. Generic reference. In: The Encyclopedia of Language and Linguistics. 2nd ed. Oxford: Elsevier, pp. 289-293.

Cinque, Guglielmo. 2010. The syntax of adjectives: A comparative study. Cambridge, MA: MIT Press.

Cinque, Guglielmo. 2014. The Semantic Classification of Adjectives. A view from Syntax. Studies in Chinese Linguistics 35(1), pp. 1-30.

GRIMM, Scott - Levin, Beth. 2017. Furniture and Other Artifactual Aggregates. Manuscript. 
Kennedy, Christopher. 2012. Adjectives. In: Russel, Gillian - Graff FARA, Delia, eds. Routledge Companion to Philosophy of Language. New York: Routledge, pp. 347-360.

KrIfKA, Manfred - Gerstner, Claudia. 1987. An Outline of Genericity. Seminar für natürlichsprachliche Systeme der Universität Tübingen.

KRIFKA, Manfred et al. 1995. Introduction to genericity. In: CARLSON, Gregory - PELletier, Francis Jeffrey, eds. The Generic Book. Chicago: University of Chicago Press, pp. 1-124.

McNally, Louise - BoledA, Gemma. 2004. Relational Adjectives as properties of kinds. Colloque de Syntaxe et Sémantique à Paris.

McNally, Louise. 2016. Modification. In: The Cambridge Handbook of Formal Semantics. Cambridge: Cambridge University Press, pp. 442-464.

MORZYCKI, Marcin. 2008. Nonrestrictive modifiers in nonparenthetical positions. In: McNAlly, Luise - Kennedy, Christopher, eds. Adjectives and adverb: Syntax, semantics, and discourse. Oxford: Oxford University Press, pp. 101-122.

Morzycki, Marcin. 2016. Modification. Cambridge: Cambridge University Press.

SPenCer, Andrew. 1988. Bracketing paradoxes and the English lexicon. Language 64, pp. 663-682.

WĄGIEL, Marcin. 2014. From kinds to objects: Prenominal and postnominal adjectives in Polish. In: Veselovská, Ludmila - Janebová, Markéta, eds. Complex Visibles Out There. Proceedings of the Olomouc Linguistics Colloquium 2014: Language Use and Linguistic Structure. Olomouc: Palacký University, pp. 457-475.

Acknowledgment: I am very grateful to Pavel Caha, who read the first draft of the paper, for stimulating discussion about the analysis. I am also indebted to Marcin Wągiel for very helpful comments on the earlier version of this paper. Next, I would like to thank Mojmír Dočekal for supporting me in linguistics.

\author{
Iveta Šafratová \\ Masaryk University \\ Department of Linguistics and Baltic Languages \\ Jaselská 18, 602 oo Brno \\ Czech Republic
}

Georg-August-Universität Göttingen

Seminar für Englische Philologie

Käte-Hamburger-Weg 3, 37073 Göttingen

Germany

safratova@mail.muni.cz 